\title{
On Feminine Consciousness Reflected by Jane Austen's Works
}

\author{
Li Zhaoying \\ Jilin Business and Technology College, Changchun 130507,China
}

Key words: Jane Austen; feminine consciousness; views on marriage

\begin{abstract}
Jane Austen, whose works were mainly based on the squire women's marriages and family life and depicted a world she wanted to express through her meticulous, keen observation and lively, funny words, was a famous female British novelist. The style of her works was relaxing, humorous, and dramatic. Women's character, values, and marriage in her works revealed Austen's own feminine consciousness. This thesis, starting with Austen's works, interprets and makes a brief analysis on the feminine consciousness of her works.
\end{abstract}

\section{Introduction}

Jane Austen, who created many vivid female images in her works, was one of the most famous female writers in the history of English literature. Because Austen was born in a well-off family, living all her life in the feudal countryside among a small circle of life, her works were always limited to ordinary squire daughters' love stories. She described social problems in a unique way from a distinct perspective and keen observation. These heroines pursued independence, equality and strong self-awareness in love and marriage, which highlighted the awakening of feminine consciousness.

\section{Background}

In the 18th century, England was still in a patriarchal society, and the male was the mainstream of the society. The image of women was rude or shaped by men's wishes, which had a great impact on Austen's thoughts. Men tended to use various ways to please women, but women could only get financial security through their beauty.

In this era, marriage was the center of women's life and there would not be any job available to them except marriage. Receiving education, learning etiquette, etc. were the tickets to upper society for those noble ladies born wealthy, and one day they could use them to attract their future husbands. Women's dependence on men, and becoming poor appendages to them, greatly stimulated Austen's creative desire. In her works, women were no longer accessories, but had their existence and self-awareness.

\section{The Feminine Consciousness in Austen's Works}

Sense of Equality. In Austen's times, there was no equality between men and women in England. Austen sharply commented on women's social status in her works: economic status determined social status. In "Pride and Prejudice", Elizabeth, pursuing independence, was a learned, thoughtful woman. She was almost a near-perfect image of women portrayed by Austen, disdained the so-called social norms, and satirized inequality, stupid behavior. For example, she once indecently walked alone three miles to visit a sick sister, appearing shabbily in front of "elites", being looked down upon by Miss Bingley, and criticized as "a wild, impolite, and frivolous 
countryman". Although she didn't have humble attitude or elegant behavior, her own shining points won Darcy's admiration, which was undoubtedly a great ridicule of Miss Bingley's pretense. Other protagonists, such as the heroine Emma in "Emma", was keen to contribute to someone else's marriage, but she herself never wanted to marry. She felt that marriage would make her lose herself. She said, "I believe that very few married women become housewives, or masters like me in Hatfield. I will never be so loved or appreciated. Other men can hardly spoil me as my father does. " This was a reflection of her pursuit of self. Although these characters had some shortcomings, there was a big difference between traditional women and themselves.

In order to highlight these shining points, Austen also portrayed other women's images, which could be roughly divided into two categories: 1 . submitting to the secular world. Like Elizabeth's sister Jane, Harriet in "Emma", etc., they were usually kind, gentle and delicate, submitting to others' views and the secular world without their own thoughts; 2. standing in men's position. Like Mrs. Palmer, Lady Catherine, they blindly indulged their husbands, thinking from their husbands' standpoint, always showing off their own talents, very stupid and boring.

Austen also described another kind of anti-traditional woman, Annie in "Persuasion", who was different from Elizabeth in conversation or behavior. She was mature, observant, having a thorough understanding of human nature. In life she had a smart brain, mature thinking, but lacked appreciation from her family. Her godmother appreciated her but didn't understand her; her friends liked her but they had no common language. Her soul was lonely, but also noble. She built a castle for her own ideas. In her castle, she used her own ways to communicate with herself, comforted her soul, revolted against the secular living environment and chased her own personal freedom and equality.

Views on Marriage. Lu Xun once said, "In a private-ownership society, women were treated as private commodities." In a patriarchal society, it was hard to achieve equality between love and marriage. And it was just the female writers, pursuing equality between love and marriage, that had feminine consciousness. Compared with the description of love by male writers, female writers depicted love in a more delicate way. They were better at expressing their feelings, ideals. It was generally believed that traditional marriage was determined by men's economic conditions. If a man was rich enough to bear the family costs, then there was no reason for a woman to refuse his pursuit. However, it was undoubtedly painful for a woman to choose a marriage not by their own preferences. Austen believed a legitimate marriage was based on mutual respect, not on property or status.

In "Emma", the description of the Bennett family revealed the profound issues of inequality between men and women in love. Due to the prevailing social system and customs, property must be inherited by male heirs, and silly, superficial Collins inherited all the property, leading to Mrs. Bennett and her daughters' tragic life. And Collins also took advantage of this advantage to propose to Elizabeth in a merciful way and thought that the other side would feel extremely honored to accept. However, Elizabeth's refusal was just a revolt against this secular custom. She did not pursue such a marriage without love, only with property. Her goal was not to marry a rich man. She yearned for true love, hoping to have love based on equality and mutual respect. When the nobleman, Darcy, having a lot of incomes each year, proposed to her, Elizabeth also refused him at the beginning, because she thought Darcy impaired her dignity. Elizabeth's refusal forced Darcy to reflect on himself. Her words and deeds influenced Darcy and changed his arrogance. Finally, she accepted Darcy's request, getting her own happiness.

In "Sense and Sensibility", Austen expressed another sensible view on love. Dashwood's two daughters, the elder daughter Elinor and the younger one Marianne, were very good, gentle and 
kind, having independent and critical opinions on things. Compared with her sister, Marianne was less careful. With the development of the story, the two sisters were both faced with lovelorn troubles. After Elinor knew her beloved had got engaged, she didn't appear miserable, though painful at heart, so her family had no way to learn of the truth from her. But when Marianne broke up with her sweetheart, she completely lost the spirits, immersing herself in sheer grief. This was the description of reasons and emotions. And Austen preferred women should have their own independent personalities, so as to maintain sober in love and marriage, to make a real choice.

Austen cleverly put some unfair treatment of British society into her articles and performed a drama through her protagonists.

\section{Limitations of the Feminine Consciousness in Austen's Works}

Austen's feminine consciousness was quite progressive at the time, but that was not determined by her female identity. In many of her works, Austen subjectively criticized and satirized a lot of women. This phenomenon was closely related to Austen's living atmosphere. While Austen recognized the social injustices against women, she inevitably accepted the influences brought by the patriarchal society. Under the prevailing social atmosphere, women could hardly find supports from the outside world to increase their abilities and wisdom, so they could only be limited to a small circle of exchange.

In many works, most of the writers tended to think that women were oppressed by the external environment, while Austen attributed their intellectual defects to themselves. This depended on Austen's family background. Austen's family, devout Christians, belonged to the middle class. Her works, influenced by the outside world, showed the initial formation of feminine consciousness. But under the influence of her education and the environment, her works, on the one hand, appealed to women's liberation, but on the other hand placed women among marriage and family. Her protagonists were all confined to the family circle to struggle or to seek liberation, never trying to strive for their economic independence outside. However, Jane Eyre described by Charlotte went further. Although Jane Eyre pursued economic and personal independence, but in the end she was still arranged into her marriage by the writer. Therefore, all the heroines described by Austen or Charlotte Bronte came to the same end: obtain a satisfactory marriage, an ideal husband.

It could be seen that the reason why they tried to improve their self-cultivation or to have a clever mind, a keen sense, was that they wanted to add charm to their pursuit of love and marriage. In the end, they still submitted to the secular world, admitted their status, and enriched themselves to look for good husbands on the family stage.

In short, the progressive significance of feminine consciousness highlighted by Austen's works was powerful. The impact of the prevailing society and family education determined this conflict of her works. But the conflict could not cover the influence on the development of feminine consciousness.

\section{Conclusion}

Austen's works had unique ideas which expressed one viewpoint: in love and marriage, women must have their own independent economics and personalities, their own abilities to distinguish between right and wrong so as to make accurate judgments, rational analyses and right choices.

Whether in the 18th century England or the present 21st century, we should fully combine rationality and sensibility, raise feminine consciousness, self-awareness and sense of equality so as to shoulder the responsibility of the times and better pursue our own marriage and love. 


\section{References}

[1] Kirkham, Margaret Jane Austen. Feminism and Fiction. London \& Atlantic Highlands. NJ,1997.

[2] Parrill, Sue Jane Austen on Film and Television:A Critical Study of the Adaptations.Jefferson. North Carolina and London: McFarland \& Company.Inc.Publishers,2002.

[3] Monaghan, David,Jane Austen in a social context[M].The Macmillan Press,1981.

[4] Jane Austen. Emma [M]. Oxford: Oxford University, 1971.

[5] Jane Austen. Sense and Sensibility [M]. New York: The Book League of America, 1995. 